\title{
Editorial
}

Journal of Innate

Immunity
J Innate Immun 2019;11:1-2

DOI: $10.1159 / 000495685$

Published online: December 11, 2018

\section{Catch Me if You Can or Actors on the Run}

What have Leonardo DiCaprio and streptococci in common? One could guess that Leonardo DiCaprio probably may have suffered from a strep throat during his childhood, but there is no reported evidence. Also, the wordplay that the famous actor had to learn how to deal with compliments while bacterial pathogens have acquired strategies to deal with complement seems to be far-fetched, though a little bit closer to the truth. In Catch me if you can, one of DiCaprio's most famous movies, he plays Frank Abagnale, a man with many faces, who manages to escape his imprisonment by the FBI. Like Frank Abagnale, streptococci have also evolved mechanisms to camouflage their outfit in order to run away from the innate immune police. The review article by Emert and Laabei [1], published in this issue, provides the reader with an excellent and a timely overview of the tricks employed by these bacteria to fool the immune system. Recent studies have underlined the importance of complement in eradicating invading bacteria [2] or being involved in other essential innate immune pathways such as the kallikrein/kinin system [3], making the complement system an interesting target for drug development [4]. However, as exemplified by Laabei and Ermert, bacteria are often one step ahead, which makes hunting the catch a difficult undertaking. Likewise, the second review article in this issue, published by
Watson et al. [5], is dealing with innate immune recognition. However, instead of bacteria, the focus is on viral fusion proteins which can be targeted by lung collectins such as surfactant proteins A and D. Notably, collectins are mainly discussed in terms of their antibacterial activity $[2,6]$ or as triggers of inflammation [7]. Therefore, the article by Watson and coworkers is highlighting another very important aspect of this class of proteins, that is their ability to clear viral pathogens. Apart from collectins, the human body has developed other antiviral strategies. For instance, $\mathrm{Xu}$ et al. [8] show in their article that human cervical epithelial cells are able to evoke the induction of cellular HIV restriction factors that mediate HIV inhibition. This process seems to engage an involvement of the interferons IFN- $\beta$ and IFN- $\lambda$ s, respectively. Within the last years, Journal of Immunity has published many articles involving interferon signaling [9-13], emphasizing the important role of these inflammatory immune mediators in fighting viral infections. Future work will hopefully bring us the answer whether IFN- $\lambda$ s can be used as therapeutic target for the treatment of HIV infection. Aside from the contribution by $\mathrm{Xi}$-Qiu Xu and collaborators, four articles of the current issue investigate phagocytosing cells [14-17]. Their findings underline that the cellular innate immune response constitutes another essential defense system

\begin{tabular}{ll}
\hline KARGER & $\begin{array}{l}\text { ( ) } 2018 \text { The Author(s) } \\
\text { Published by S. Karger AG, Basel }\end{array}$ \\
E-Mail karger@karger.com & This article is licensed under the Creative Commons Attribution- \\
www.karger.com/jin & NonCommercial-NoDerivatives 4.0 International License (CC BY- \\
& NC-ND) (http://www.karger.com/Services/OpenAccessLicense). \\
Usage and distribution for commercial purposes as well as any dis- \\
tribution of modified material requires written permission.
\end{tabular}


against invading pathogens, being orchestrated by the complement system and activation of pattern recognition receptors [18]. Amazingly, all four articles deal with different immunological aspects telling us that there is still no redundancy when conducting research on the innate immune system. Thus, as long as the actors of the innate immune system continue to perform and can surprise us, the Journal of Innate Immunity is not steering the boat towards an iceberg, as it happened in another famous Leonardo DiCaprio movie.

Arne Egesten, Lund

Heiko Herwald, Lund

\section{References}

1 Ermert D, Laabei M. Catch Me if You Can: Streptococcus pyogenes Complement Evasion Strategies. J Innate Immun. 2018 DOI: $10.1159 / 000492944$.

2 Hwang I, Mori K, Ohtani K, Matsuda Y, Roy N, Kim Y, et al. Collectin Kidney 1 Plays an Important Role in Innate Immunity against Streptococcus pneumoniae Infection. J Innate Immun. 2017;9(2):217-28.

3 Irmscher S, Döring N, Halder LD, Jo EA, Kopka I, Dunker C, et al. Kallikrein Cleaves $\mathrm{C} 3$ and Activates Complement. J Innate Immun. 2018;10(2):94-105.

4 Heesterbeek DA, Angelier ML, Harrison RA, Rooijakkers SH. Complement and Bacterial Infections: From Molecular Mechanisms to Therapeutic Applications. J Innate Immun. 2018 DOI: 10.1159/000491439.

5 Watson A, Phipps MJ, Clark HW, Skylaris CK, Madsen J. Surfactant Proteins A and D: Trimerized Innate Immunity Proteins with an Affinity for Viral Fusion Proteins. J Innate Immun. 2018 DOI:10.1159/000492974.

6 Sadio M, Tourneur E, Bens M, Goujon JM, Vandewalle A, Chassin C. Cyclosporine A Induces MicroRNAs Controlling Innate Immunity during Renal Bacterial Infection. J Innate Immun. 2018;10(1):14-29.

7 Dong X, Wu W, Ma L, Liu C, Bhuckory MB, Wang L, et al. Collectin-11 Is an Important Modulator of Retinal Pigment Epithelial Cell
Phagocytosis and Cytokine Production. J Innate Immun. 2017;9(6):529-45.

8 Xu XQ, Guo L, Wang X, Liu Y, Liu H, Zhou $\mathrm{RH}$, et al. Human Cervical Epithelial Cells Release Antiviral Factors and Inhibit HIV Replication in Macrophages. J Innate Immun. 2018 DOI: $10.1159 / 000490586$

9 Kusaka Y, Kajiwara C, Shimada S, Ishii Y, Miyazaki $\mathrm{Y}$, Inase $\mathrm{N}$, et al. Potential Role of Gr-1+ CD8+ T Lymphocytes as a Source of Interferon $-\gamma$ and M1/M2 Polarization during the Acute Phase of Murine Legionella pneumophila Pneumonia. J Innate Immun. 2018; 10(4):328-38.

10 Crosse KM, Monson EA, Beard MR, Helbig KJ. Interferon-Stimulated Genes as Enhancers of Antiviral Innate Immune Signaling. J Innate Immun. 2018;10(2):85-93.

11 Yan R, van Meurs M, Popa ER, Jongman RM, Zwiers PJ, Niemarkt AE, et al. Endothelial Interferon Regulatory Factor 1 Regulates Lipopolysaccharide-Induced VCAM-1 Expression Independent of $\mathrm{NF \kappa B}$. J Innate Immun. 2017;9(6):546-60.

12 Feng J, Cao Z, Wang L, Wan Y, Peng N, Wang $\mathrm{Q}$, et al. Inducible GBP5 Mediates the Antiviral Response via Interferon-Related Pathways during Influenza A Virus Infection. J Innate Immun. 2017;9(4):419-35.

13 Kirkham CL, Aguilar OA, Yu T, Tanaka M, Mesci A, Chu KL, et al. Interferon-Dependent
Induction of Clr-b during Mouse Cytomegalovirus Infection Protects Bystander Cells from Natural Killer Cells via NKR-P1B-Mediated Inhibition. J Innate Immun. 2017;9(4): 343-58.

14 Francis A, Bosio E, Stone SF, Fatovich DM, Arendts G, MacDonald SP, et al. Markers Involved in Innate Immunity and Neutrophil Activation are Elevated during Acute Human Anaphylaxis: Validation of a Microarray Study. J Innate Immun. 2018 DOI: $10.1159 / 000492301$.

15 Ponath V, Heylmann D, Haak T, Woods K, Becker H, Kaina B. Compromised DNA Repair and Signalling in Human Granulocytes. J InnateImmun.2018DOI:10.1159/000492678.

16 Riestra AM, Valderrama JA, Patras KA, Booth SD, Quek XY, Tsai CM, et al. Trichomonas vaginalis Induces NLRP3 Inflammasome Activation and Pyroptotic Cell Death in Human Macrophages. J Innate Immun. 2018 DOI: $10.1159 / 000493585$.

17 Oppong-Nonterah GO, Lakhdari O, Yamamura A, Hoffman HM, Prince LS. TLR Activation Alters Bone Marrow-Derived Macrophage Differentiation. J Innate Immun. 2018 DOI: $10.1159 / 000494070$.

18 Gasteiger G, D’Osualdo A, Schubert DA, Weber A, Bruscia EM, Hartl D. Cellular Innate Immunity: An Old Game with New Players. J Innate Immun. 2017;9(2):111-25. 